\title{
Editor's Introduction
}

\section{ABOUT THIS ISSUE}

I write with mixed feelings for this Editor's Introduction: I am excited about the articles and reviews being published in this issue by those in our profession, while also concerned about the global news over the last year, in particular regarding society's efforts to address climate change. It is difficult to think and act locally when our actions are only slowly moving forward (even reverse for some countries) to prioritize how we are changing the global environment.

I appreciate each piece in this issue because of the contributions being made to Landscape Journal. The pieces span and interweave topics that transcend design, planning and management of the land. First, M. Elen Deming (North Carolina State University) and other community leaders pay tribute to Pat D. Taylor for leaving a lasting mark on the Council of Educators in Landscape Architecture (CELA) and beyond - thank you Pat. Next, I am proud to have worked with Michael Rios and N. Claire Napawan (University of California, Davis) to bring their insightful letter focused on diversity and inclusion by design to Landscape Journal readers in advance of the CELA 2019 conference that is themed "Engaged Scholarship: Bringing Together Research, Teaching, and Service.” Claire and Michael challenge each one of us to integrate equity, diversity, and inclusion with community, public, and civic engagement at the conference and more importantly in everything we do. I would like to remind readers of a previous Landscape Journal issue about Race, Space, and the Destabilization of Practice (2007, Volume 26, Number 1) with Dianne Harris (currently Senior Program Officer at the Andrew W. Mellon Foundation) as Guest Editor, while M. Elen Deming and James Palmer were the Editors. This issue focused on the relationships between the built form of the environment, the social construction of race, and minoritization in the United States. Dianne's introductory essay established central themes in the issue and suggests directions for additional research. I have enjoyed re-reading this issue and welcome additional scholarly submissions in this area.

We are publishing four peer-reviewed articles in this issue that are very different in the topics and approaches they take for their scholarship. William Langley, Robert Corry, and Robert Brown explore the intersection and synthesis of the Core Knowledge Domains of Landscape Architecture over the last several decades. Benjamin George presents a focused study about different instructional approaches for a basic graphics course with results that have implications for how we may all teach using a mix of different technologies and structures to help people learn more effectively. Angela Kreutz, Victoria Derr, and Louise Chawla document a design and implementation process that identifies opportunities and challenges when integrating different constituencies over time. Finally, Julie Stevens, Barb Toews, and Amy Wagenfeld invite the academic and practice communities to learn about and design the correctional landscapes that house more than two million people in the United States.

I am delighted to include several timely conference and book reviews in this issue. The five reviews include a symposium about the aesthetics of planting design, a book about Lawrence Halprin, another on biophilic city planning \& design, and two books about Roberto Burle Marx. I sincerely enjoyed working with these scholars to bring their insights to you in these short, yet important contributions to Landscape Journal.

This lead me to briefly turn my focus to the multiple ways to further develop and advance Landscape Journal. We have worked with authors representing six continents and 22 countries since the beginning of 2017 
and we sincerely appreciate the opportunity to review submissions and work with emerging and seasoned scholars. We are continually gratified by the diligence and professionalism shown by almost 100 peer reviewers who represent at least 10 countries. Your work is essential and is much appreciated-THANK YOU. Although these might be the most recognized ways to contribute to Landscape Journal, there are additional ways that are valuable. A simple way to support Landscape Journal is to cite a Landscape Journal article in at least one of your publications this year. You can use Landscape Journal articles in your courses and studios and direct students to download articles through your institution's library in order to show demand for the institution's subscription. If you have curated a course/ studio reference list that includes many Landscape Journal articles, I welcome the opportunity to learn about what you are doing. You can sign up for an electronic table of contents (eTOC) to be delivered by email when a new issue is published at http://j.uwpress. org/site/subscriptions/etoc.xhtml. I will note that depending on how you subscribe or your institution provides access to Landscape Journal, there can be a delay in article availability. For instance, I have seen a two-month unexplained time lag by EBSCO Host Business Source Complete in providing article access while Highwire and Project MUSE have been much more timely.

Finally, I would like to hear your feedback on two new sections I am planning for future issues. The first new section has a working title of "In Focus." Similar in concept as a Letter to the Editor, this section will allow for photoimage essays that are intended to tell a current story, comment on the profession, remind us why we are in this field, or call the profession to action, etc. Historical imagery is not an anticipated emphasis of these submissions although that imagery could be used. The second new section is a review of recently implemented work with an anticipated section title of "Perspectives." This section's intent is to learn from works that have been in effect or built for at least five years and no longer than ten years. In some parts of our field, there is a predominant focus on built work quantification. This section's purpose is to provide a scholarly outlet for experiential and qualitative review using observational research methods. Over time, I can see this section becoming very useful in instructional as well as practice settings. This section offers an important way to link theory and research methods with recently implemented work(s).

In contrast to so many exciting happenings here at Landscape Journal, the global climate continues to change more dramatically than what has been previously forecasted. I wish to draw your attention to three publications in particular. First is the Intergovernmental Panel on Climate Change (IPCC) - “Global Warming of $1.5^{\circ} \mathrm{C}$, an IPCC special report on the impacts of global warming of $1.5^{\circ} \mathrm{C}$ above pre-industrial levels and related global greenhouse gas emission pathways, in the context of strengthening the global response to the threat of climate change, sustainable development, and efforts to eradicate poverty" (https://report.ipcc. ch/sr15/index.html) published on 8 October 2018. This was followed by the United States government releasing the Fourth National Climate Assessment, Volume II: Impacts, Risks, and Adaptation in the United States (https://nca2018.globalchange.gov/) on 23 November 2018. We close out 2018 with the 24th Conference of the Parties to the United Nations Framework Convention on Climate Change (COP24 Katowice) (https:// cop24.gov.pl/) being declared a success on 15 December 2018, in Warsaw, Poland. However, Steve Austin, ASLA (Washington State University), wrote a thoughtful piece entitled "Can we get to Zero?: Landscape architecture can mitigate carbon emissions but it is also implicated among the causes" in the June 2017 issue of Landscape Architecture Magazine. As best as I can see, just two bloggers liked the piece and not even one person left a comment at https://landscapearchitec turemagazine.org/2017/06/08/can-we-get-to-zero/ at now 18 months after publication. These events and publications should be making us profoundly rethink the ways we are living our personal and professional lives and become agents of change. For example, we have and are making changes in the way Landscape Journal is published, including increasing the use of renewable energy in the Editorial Office operations as well as the use of Forest Stewardship Council (FSC) (https://us.fsc.org/en-us) products for the Landscape Journal print edition. On a personal level, I am questioning my own choices and am changing the way I live in order to be part of a solution set going forward. For instance, I am choosing to reduce my conference travel by looking to attend "virtual" session conferences 
when available such as the Fifteenth International

Conference on Environmental, Cultural, Economic \&

Social Sustainability by On Sustainability (https://

onsustainability.com/2019-conference). Are there conferences you normally attend and/or could influence that might use this approach?

Toward the end of Austin's piece, he indicates some reasons why the world needs landscape architects and raises what, unfortunately, appear to be largely rhetorical questions for the community. I humbly and emphatically ask you to read these four climate change related documents and become innovative change leaders in your personal and professional lives.

BL 